\title{
Serum leptin and body mass index in a sample of Egyptian multiple sclerosis patients
}

\author{
Mohamed A. Abd Elhafeez*, Dina A. Zamzam, Mohamed M. Fouad, Hala M. Elkhawas and Hend A. Abdel Rahman
}

\begin{abstract}
Background: The adipose tissues release pro-inflammatory cytokines such as leptin that can be considered a link between obesity and autoimmunity. This study aimed to investigate a possible correlation between BMI, serum leptin, and multiple sclerosis (MS).

Methods: This case-control study recruited consecutively 169 patients from our MS Unit and 50 healthy controls. Clinical history and examination with Expanded Disability Status Scale (EDSS) scoring were done for all patients. Calculation of body mass index (BMI) and measurement of serum leptin level were done for patients and controls.

Results: The case group had significantly higher BMI (mean of $26.85 \pm 6.06$ versus $19.55 \pm 1.62 ; \mathrm{P}<0.001$ ) and higher serum leptin levels (median [IQR] of $280 \mathrm{pgm} / \mathrm{ml}$ [175-525] versus $102.5 \mathrm{pgm} / \mathrm{ml}$ [80-125]; P $<0.001$ ) compared to the control group. Serum leptin levels did not have a correlation with either disease activity or degree of disability.
\end{abstract}

Conclusions: MS patients had significantly higher BMI and higher serum leptin levels compared to controls.

Keywords: Serum leptin, Body mass index, Multiple sclerosis, Egypt

\section{Introduction}

Obesity is associated with a chronic inflammatory state, due to the secretion of pro-inflammatory proteins in the blood from the adipose tissue [1], and can affect the immune system by promoting a pro-inflammatory state [2]. These proteins are associated with an increase in the adipokines; a family of molecules with effects on inflammatory and autoimmune diseases [3]. Leptin is one of the cytokines that is released primarily from adipocytes and exhibits neuroendocrine properties influencing energy balance.

Leptin plays a role in the regulation of the immune system. It has a possible pro-inflammatory role through stimulating the proliferation of effector $\mathrm{T}$ cells and inhibiting the transformation of naive $\mathrm{T}$ cells into the anti-

* Correspondence: dr_mohammed_3ly@yahoo.com

Neurology department, Ain Shams University Hospital, Abbasia, Cairo, Egypt inflammatory $\mathrm{T}$ helper 2 cells. Additionally, leptin increases macrophage and monocyte proliferation rates, thereby increasing the levels of inflammatory cytokines $[4,5]$.

This study aimed to investigate a possible correlation between body mass index (BMI), serum leptin level, and multiple sclerosis (MS) in a sample of Egyptian MS patients.

\section{Methods}

This was a cross-sectional, observational, case-control study, done at our MS unit. It included 169 definite MS patients (diagnosis based on clinical, laboratory, and radiological features of MS) as the case group and 50 healthy individuals matched for age and sex as the control group. The patients were recruited consecutively after fulfillment of the inclusion criteria and their agreement to participate in the study during the period from January 2017 to January 2018. MS patients were included if the age ranges from 18 to 50 years from both

\section{Springer Open}

(๑) The Author(s). 2020 Open Access This article is licensed under a Creative Commons Attribution 4.0 International License, which permits use, sharing, adaptation, distribution and reproduction in any medium or format, as long as you give appropriate credit to the original author(s) and the source, provide a link to the Creative Commons licence, and indicate if changes were made. The images or other third party material in this article are included in the article's Creative Commons licence, unless indicated otherwise in a credit line to the material. If material is not included in the article's Creative Commons licence and your intended use is not permitted by statutory regulation or exceeds the permitted use, you will need to obtain permission directly from the copyright holder. To view a copy of this licence, visit http://creativecommons.org/licenses/by/4.0/. 
genders and were excluded if there was comorbidity of hypothyroidism. The records of each patient included demographic data, medical history, and key episodes in the course of MS. At the time of blood sample collection, all of the patients were assessed, through detailed history taking and neurological examination, for evidence of recent relapse (within the last 30 days) to determine active MS patients. Expanded Disability Status Scale (EDSS) scoring was done by a trained neurologist to assess disability for the patients.

Body mass index (BMI) was calculated by dividing the body mass in kilograms by the square of the body height in meters expressed in $\mathrm{kg} / \mathrm{m}^{2}$ for both patients and controls. Blood samples were collected from all the participants after they gave their written informed consent to this study and were allowed to clot for $2 \mathrm{~h}$ at room temperature or overnight at $4{ }^{\circ} \mathrm{C}$ before centrifugation for $20 \mathrm{~min}$ at approximately $1000 \times g$. Then, the supernatant was collected and the leptin level in the serum was determined by the sandwich enzyme-linked immunesorbent assay (ELISA) technology. The procedure was done according to the manufacturer's instruction as supplied with a kit from the Cloud Clone Corporation.

\section{Statistical methods}

Data entry, processing, and statistical analysis were carried out using MedCalc ver. 15.8. Tests of significance (chi-square, ANOVA, Kruskal-Wallis, and Spearman's correlation coefficient) were used. Data was presented and suitable analysis was done according to the type of data (parametric and non-parametric) obtained for each variable. $P$ values of less than 0.05 (5\%) was considered to be statistically significant.

Descriptive statistics were done for quantitative data as minimum and maximum of the range as well as mean \pm SD (standard deviation) for parametric numerical data, while the median and inter-quartile range (IQR) for nonparametric numerical data. Chi-squared test was used to examine the relationship between two qualitative variables, and ANOVA test was used to assess the statistical significance of the difference between more than two study group means. Kruskal-Wallis test was used to assess the statistical significance of the difference of a nonparametric variable between more than the two study groups. The correlation analysis (using Spearman's method) was used to assess the strength of association between two quantitative variables. The correlation coefficient denoted symbolically "rho" defines the strength and direction of the linear relationship between two variables.

\section{Results}

Analysis of the demographic data showed that the case group included 125 females (74.0\%) and 44 males (26.0\%), and their age ranged from 18 to 55 years with a mean of
$33.75 \pm 8.54$. While the control group included 31 females $(62.0 \%)$ and 19 males (38.0\%), and their age ranged from 19 to 55 years with a mean of $31.56 \pm 9.79$. The comparison between both groups revealed no statistical significant difference as regards age $(P=0.126)$ and gender $(P=0.101)$.

As regards the clinical characteristics of the case group, the age of patients at the onset of disease ranged from 13 to 39 years with a mean of $25.30 \pm 8.34$, and the duration of illness had a median (IQR) of 5 years [3-9] ranging from 0.4 to 29 years. One hundred forty patients (82.8\% of the case group) had the diagnosis of relapsing remittent MS, and 29 patients $(17.2 \%)$ had the diagnosis of secondary progressive MS. Thirty-eight patients ( $22.5 \%$ of the case group) had evidence of activity, while 131 patients $(77.5 \%)$ had no evidence of activity. The EDSS scores of the patients ranged from 0 to 6.5 with a median (IQR) of 3.5 (2-5.5). Patients were classified according to EDSS score into 74 patients (43.8\% of cases) with mild disability (EDSS score < 3), 57 patients $(33.7 \%$ of cases) with moderate disability (EDSS score ranging from 3 to 6 ), and 38 patients (22.5\% of cases) with severe disability (EDSS score $>6$ ).

The weight of the patients ranged from 40.4 to $121.2 \mathrm{~kg}$ with a mean of $73.15 \pm 17.59$ and their heights ranged from 145 to $188 \mathrm{~cm}$ with a mean of $164.81 \pm 8.13$. The patients' BMI ranged from 15.8 to 41.2 with a mean of 26.85 \pm 6.06 . According to 2004 WHO classification, 5 patients $(3.0 \%)$ were underweight (BMI < 18.50), 70 patients (41.4\%) were within the normal range of BMI (BMI ranging from 18.50 to 24.99$), 58$ patients (34.3\%) were overweight (BMI ranging from 25.00 to 29.99), and 36 patients (21.3\%) were obese (BMI $\geq 30.00$ ).

Among the control group, their weights ranged from 42 to $98 \mathrm{~kg}$ with a mean of $59.37 \pm 5.19 \mathrm{~kg}$ and their heights ranged from 144 to $189 \mathrm{~cm}$ with a mean height of $163.48 \pm 11.79$. The controls' BMI ranged from 18.1 to 23.6 with a mean BMI was $19.55 \pm 1.62$.

The comparison between the patients and control group showed non-significant difference as regards the height $(P=0.364)$, while patients had significantly higher weights $(P<0.001)$ and higher BMI $(P<0.001)$.

The laboratory data showed that the serum level of leptin among the case group ranged from 30 to 1000 $\mathrm{pgm} / \mathrm{ml}$ with a median (IQR) of $280 \mathrm{pgm} / \mathrm{ml}(175-525)$, while ranged from 80 to $125 \mathrm{pgm} / \mathrm{ml}$ with a median (IQR) of $102.5 \mathrm{pgm} / \mathrm{ml}(80-125)$ among the control group. The comparison between the case and control groups showed that the patients had significantly higher serum levels of leptin $(P<0.001)$ (Fig. 1, Table 1$)$.

The degree of disability was correlated with the demographic data, height, weight, BMI, age at the onset of disease, and duration of illness, yet there was nonsignificant correlation between the degree of disability and BMI (Table 2). 


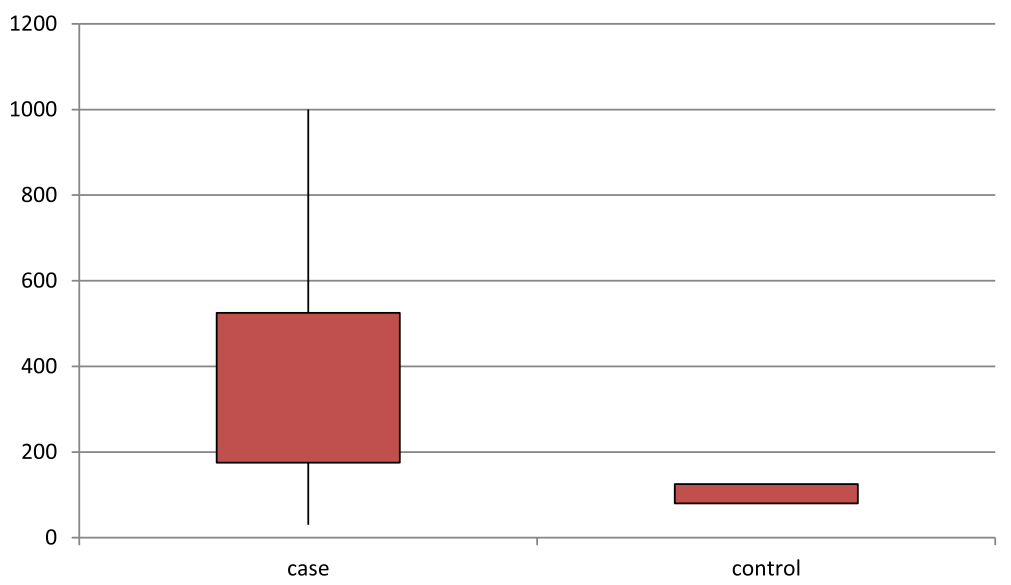

Fig. 1 Comparison of serum leptin levels between case and control groups

The comparison of serum leptin levels between RRMS and SPMS patients showed a non-significant difference $(P=$ 0.993), also there was a non-significant difference between active and non-active MS patients $(P=0.692)$ (Table 3$)$.

There were no significant correlations between the serum leptin level and age of the patient, age at onset of disease, duration of illness, BMI, or EDSS score (Table 4).

\section{Discussion}

This study showed that $34.3 \%$ of MS patients were overweight and $21.3 \%$ were obese $(55.6 \%$ of the patients had a BMI 225 ). This can be partly due to a national problem in Egypt; as in 2015, among the 20 most populous countries, the highest level of agestandardized adult obesity was observed in Egypt (35.3\% of the population) [6]. This finding was previously corroborated in one Egyptian study among MS patients [7] which shall draw the attention of health care providers to the issue of obesity among the
Egyptian MS patients and may suggest an increase in MS risk among people with elevated BMI.

Obesity in early life is highly relevant as a susceptibility factor and causally related risk for late MS development [8]. Several observational studies have suggested that high BMI is associated with an increased risk of MS. For example, two studies stated that increased BMI at the age of 18 was associated with nearly two-fold increase in the risk of MS [9, 10]. Elevated BMI has shown to promote a pro-inflammatory state, due to the remarkable properties of the adipose tissue, which might be related to the pathogenesis of MS [2]. A potential mechanism for such association has been suggested is that obese people have lower serum levels of vitamin $\mathrm{D}$ metabolites than do normal-weight people [7], and vitamin D deficiency has been suggested lately as one of the environmental risk factors for MS. The association between obesity and MS suggests that prevention of adolescent obesity may contribute to reduced MS risk [10].

Table 1 Comparison between patients and controls as regards demographic data, height, weight, and BMI and serum leptin level

\begin{tabular}{|c|c|c|c|c|}
\hline Variable & & Case group $(n=169)$ & Control group $(n=50)$ & $P$ \\
\hline \multirow[t]{2}{*}{ Gender } & Male & $44(26.0 \%)$ & $14(28.0 \%)$ & 0.101 \\
\hline & Female & $125(74.0 \%)$ & $36(72.0 \%)$ & \\
\hline \multirow[t]{2}{*}{ Age (years) } & Range & $18-55$ & $19-55$ & 0.126 \\
\hline & Mean \pm SD & $33.75 \pm 8.54$ & $31.56 \pm 9.79$ & \\
\hline \multirow[t]{2}{*}{ Height (cm) } & Range & $145-188$ & $144-189$ & 0.364 \\
\hline & Mean \pm SD & $164.81 \pm 8.13$ & $163.48 \pm 11.79$ & \\
\hline \multirow[t]{2}{*}{ Weight (kg) } & Range & $40.4-121.2$ & $42-98$ & 0.001 \\
\hline & Mean \pm SD & $73.15 \pm 17.59$ & $59.37 \pm 5.19$ & \\
\hline \multirow[t]{2}{*}{ BMl } & Range & $15.8-41.2$ & $18.1-23.6$ & 0.001 \\
\hline & Mean \pm SD & $26.85 \pm 6.06$ & $19.55 \pm 1.62$ & \\
\hline \multirow[t]{2}{*}{ Serum leptin (pgm/ml) } & Range & $30-1000$ & $80-125$ & 0.001 \\
\hline & Median (IQR) & $280(175-525)$ & $102.5(80-125)$ & \\
\hline
\end{tabular}


Table 2 Correlation between the degree of disability and demographic data, clinical characteristics, height, weight, and BMI

\begin{tabular}{|c|c|c|c|c|c|}
\hline \multirow[t]{2}{*}{ Variable } & & \multicolumn{3}{|l|}{ Degree of disability } & \multirow[t]{2}{*}{$P$} \\
\hline & & $\begin{array}{l}\text { Mild disability } \\
(\text { EDSS < 3) }(n=74)\end{array}$ & $\begin{array}{l}\text { Moderate disability } \\
\text { (EDSS 3-6) }(n=57)\end{array}$ & $\begin{array}{l}\text { Severe disability } \\
(\text { EDSS > 6) }(N=38)\end{array}$ & \\
\hline \multirow[t]{2}{*}{ Gender } & Male & $18(24.3 \%)$ & $11(19.3 \%)$ & $15(39.5 \%)$ & 0.081 \\
\hline & Female & $56(75.7 \%)$ & $46(80.7 \%)$ & $23(60.5 \%)$ & \\
\hline \multirow[t]{2}{*}{ Age (years) } & Range & $19-38$ & $18-40$ & $24-55$ & 0.015 \\
\hline & Mean & $32.15 \pm 7.62$ & $33.61 \pm 8.91$ & $36.35 \pm 8.93$ & \\
\hline \multirow[t]{2}{*}{ Duration of illness (years) } & Range & $0.4-19$ & $1-24$ & $4-29$ & 0.001 \\
\hline & Median (IQR) & $3(2-6)$ & $5(3-9)$ & $7.5(5-15)$ & \\
\hline \multirow[t]{2}{*}{ Age at onset of disease (years) } & Range & $14-36$ & $13-37$ & $13-39$ & 0.962 \\
\hline & Mean \pm SD & $27.11 \pm 8.01$ & $27.51 \pm 8.30$ & $27.37 \pm 9.20$ & \\
\hline \multirow[t]{2}{*}{ Height (cm) } & Range & $151-186$ & $145-186$ & $145-188$ & 0.057 \\
\hline & Mean \pm SD & $165.30 \pm 7.78$ & $162.88 \pm 6.70$ & $166.76 \pm 10.12$ & \\
\hline \multirow[t]{2}{*}{ Weight (kg) } & Range & $46.1-107.6$ & $40.4-102.5$ & $62-121.2$ & 0.168 \\
\hline & Mean \pm SD & $75.14 \pm 18.19$ & $69.58 \pm 17.79$ & $74.66 \pm 15.25$ & \\
\hline \multirow[t]{2}{*}{ BMl } & Range & $17.8-40.3$ & $15.8-41.2$ & $19.5-40.5$ & 0.580 \\
\hline & Mean \pm SD & $27.36 \pm 5.88$ & $26.25 \pm 6.95$ & $26.76 \pm 4.93$ & \\
\hline \multirow[t]{4}{*}{ BMI classification } & Underweight (BMI & $2(2.7 \%)$ & $3(5.2 \%)$ & $0(0.0 \%)$ & 0.557 \\
\hline & Normal (BMI 18.50-24.99) & $28(37.8 \%)$ & 25 (43.9\%) & $17(44.7 \%)$ & \\
\hline & Overweight (BMI 25.00-29.99) & $29(39.2 \%)$ & $18(31.6 \%)$ & $11(29.0 \%)$ & \\
\hline & Obese (BMl & $15(20.3 \%)$ & $11(19.3 \%)$ & $10(26.3 \%)$ & \\
\hline
\end{tabular}

In this study, there was no significant correlation between BMI and the degree of disability as previously reported in one study [11]. The association between obesity and disability in MS in a prospective study is one of the ongoing researches in the unit.

Serum leptin levels were significantly higher among the MS patients compared to the controls $(P<0.0001)$. This can be related to the effect of the leptin, which is one of the pro-inflammatory cytokines that are produced by the adipose tissue and leads to an overall increased level of $\mathrm{T}$ cells (via a positive effect on thymocytes), proliferation of effector $\mathrm{T}$ cells, promotion of $\mathrm{T}$ helper 1 responses, reduction of regulatory $\mathrm{T}$ cells, and inhibition of transformation of naive $\mathrm{T}$ cells into the anti-inflammatory $\mathrm{T}$ helper 2 cells. Additionally, leptin increases macrophage and monocyte proliferation rates, thereby increasing the levels of inflammatory cytokines as tumor necrosis factor-

Table 3 Comparison of serum leptin level regarding the type of MS and activity of disease

\begin{tabular}{lllll}
\hline Variable & & \multicolumn{2}{l}{ Serum leptin level } & P \\
\cline { 3 - 4 } & & Median (IQR) & Range & \\
\hline Type of MS & RRMS & $285(175-512)$ & $30-1000$ & 0.993 \\
Activity & SPMS & $250(175-800)$ & $50-1000$ & \\
& Active & $310(225-500)$ & $30-1000$ & 0.692 \\
& Non-active & $250(175-750)$ & $50-1000$ & \\
\hline
\end{tabular}

alpha, interleukin-1, and interleukin-6 [4, 5]. Leptin results in a low-grade chronic inflammatory state with the activation of the innate immune system and may increase the options for activation of autoreactive $\mathrm{T}$ cells that are involved in the pathogenesis of MS [12].

Since leptin is excreted by the adipose tissue, it was expected to find a positive correlation between serum leptin and BMI. However, there was no correlation between serum leptin level and BMI in this study, suggesting a hypothesis that an external factor seems to affect the release of the leptin from the adipose tissue rather than the amount of the adipose tissue and may postulate that cytokines released by the adipose tissue such as the leptin can

Table 4 Correlations between serum leptin level and the clinical characteristics of the patients

\begin{tabular}{lll}
\hline Variable & \multicolumn{2}{l}{ Serum leptin level } \\
\cline { 2 - 3 } & $\boldsymbol{R}$ & $\boldsymbol{P}$ \\
\hline Age & -0.141 & 0.068 \\
Age at onset of disease & -0.142 & 0.066 \\
Duration of illness & -0.065 & 0.403 \\
Weight & -0.070 & 0.367 \\
Height & -0.076 & 0.327 \\
BMl & -0.058 & 0.454 \\
EDSS & 0.060 & 0.436 \\
\hline
\end{tabular}


be considered as a risk factor for MS and can be high even in patients with normal BMI. Yet, in one study, serum leptin was correlated to BMI [13]. This study included naïve MS patients with EDSS ranging from 0 to 4. Also one study [14] reported that the correlation between serum leptin and BMI was maintained in MS patients with a low disability but lost in patients with high disability.

There was no significant correlation between serum leptin levels and degree of disability (assessed by EDSS) in this study. These conflicting results between the serum leptin and EDSS and type of MS between different studies may be partly due to different sample sizes and different inclusion and exclusion criteria, and in our study, one of the causes is most of the patients have lower disability $43.8 \%$ have EDSS less than 3 compared to $22.5 \%$ have a high disability with EDSS more than 6 .

In the study done by Evangelopoulos et al. 2014, with 89 treatment-naïve relapsing-remitting multiple sclerosis (RRMS) and clinical isolated syndrome (CIS) patients, in which serum leptin levels positively correlated with disease duration in females with RRMS, but there was a lack of association with EDSS, something they argued might be because changes in leptin secretion are not directly related to accumulating central nervous system damage. On the contrary, another study by Rotondi et al. 2013, delivered on 84 patients, showed that severe disability in patients with relapsing-remitting multiple sclerosis is associated with profound changes in leptin secretion, while BMI, the major determinant of leptin level in physiological conditions, has a minor role in determining the serum levels of leptin in MS patients with a high EDSS score.

Also the absence of a significant association between serum leptin level and disease activity in this study may point to the point that leptin has a relationship to the pathogenesis of MS but seems not to be related to the activity or degree of disability of the disease. This also has to be validated in larger scale randomized trials.

\section{Conclusion}

MS patients had significantly higher BMI compared to controls suggesting a possible increase in the MS risk among people with higher BMI. Serum leptin levels were significantly higher in MS patients. However, serum leptin levels did not have a correlation with either the activity of disease or the degree of disability.

\footnotetext{
Abbreviations

BMI: Body mass index; CIS: Clinical isolated syndrome; EDSS: Expanded Disability Status Scale; ELISA: Enzyme-linked immune-sorbent assay; IQR: Inter-quartile range; MS: Multiple sclerosis; RRMS: Relapsing-remitting multiple sclerosis; SD: Standard deviation; WHO: World Health Organization
}

\section{Authors' contributions}

HA collect the data and analyze it including the statistical analysis. MA analyzed the data, drafted the manuscript for intellectual content, and was a major contributor in writing the manuscript. MF analyzed the data and drafted the manuscript for intellectual content, and the authors read and approved the final manuscript.

\section{Funding}

Not applicable (we did not receive fund for this project).

\section{Availability of data and materials}

The datasets generated during and/or analyzed during the current study are available from the corresponding author on reasonable request.

\section{Ethics approval and consent to participate}

This manuscript was approved from the local Ethical Committee of Neurology Department, Ain Shams University, 1/12/2016. And all patients signed consents by themselves to use their tests in research purposes.

\section{Consent for publication}

All patients signed consents by themselves for publishing their cases.

\section{Competing interests}

None (the authors declare that they have no competing interests).

Received: 24 June 2020 Accepted: 26 October 2020

Published online: 11 November 2020

\section{References}

1. Ouchi N, Ohashi K, Shibata R, Murohara T. Adipocytokines and obesity linked disorders. Nagoya J Med Sci. 2012;74:19-30.

2. Würtz P, Wang Q, Kangas AJ, Richmond RC, et al. Metabolic signatures of adiposity in young adults: Mendelian randomization analysis and effects of weight change. PLoS Med. 2014;11:e1001765.

3. Tilg H, Moschen AR. Adipocytokines: mediators linking adipose tissue, inflammation and immunity. Nat Rev Immunol. 2006;6:772-83.

4. Matarese G, Carrieri PB, La Cava A, Perna F, et al. Leptin increase in multiple sclerosis associates with reduced number of CD4+ CD25+ regulatory T cells. Proc Natl Acad Sci U S A. 2005;102:5150-5.

5. Paz-Filho G, Mastronardi C, Franco CB, Wang KB, et al. Leptin: molecular mechanisms, systemic pro-inflammatory effects, and clinical implications. Arq Bras Endocrinol Metabol. 2012;56:597-607 Translated by Dep. of Translational Medicine, The John Curtin School of Medical Research, The Australian National University, Canberra, Australia.

6. GBD 2015 Obesity Collaborators, Afshin A, Forouzanfar MH, et al. Health effects of overweight and obesity in 195 countries over 25 years. N Engl J Med. 2017:377:13-27.

7. Zamzam D, Foad M, Swelam M, AbdelHafez M, et al. Vitamin D and body mass index in Egyptian multiple sclerosis patients. Mult Scler Relat Disord. 2019;28:313-6.

8. Guerrero-García JJ, Carrera-Quintanar L, López-Roa RI, Márquez-Aguirre AL, et al. Multiple sclerosis and obesity: possible roles of adipokines. Mediators Inflamm. 2016;2016:4036232.

9. Messina S, Vargas-Lowy D, Musallam A, Healy BC, et al. Increased leptin and AFABP levels in relapsing and progressive forms of MS. BMC Neurol. 2013;13:172

10. Munger $\mathrm{KL}$, Chitnis T, Ascherio A. Body size and risk of MS in two cohorts of US women. Neurology. 2009;73:1543-50.

11. Markianos M, Evangelopoulos ME, Koutsis G, Davaki P, et al. Body mass index in multiple sclerosis: associations with CSF neurotransmitter metabolite levels. ISRN Neurol. 2013;2013:981070.

12. Hedström AK, Bomfim IL, Barcellos L, Gianfrancesco M, et al. Interaction between adolescent obesity and HLA risk genes in the etiology of multiple sclerosis. Neurology. 2014;82:865-72.

13. Evangelopoulos ME, Koutsis G, Markianos M. Serum leptin levels in treatment-naive patients with clinically isolated syndrome or relapsingremitting multiple sclerosis. Autoimmune Dis. 2014;2014:486282.

14. Rotondi M, Batocchi AP, Coperchini F, Caggiula M, et al. Severe disability in patients with relapsing-remitting multiple sclerosis is associated with profound changes in the regulation of leptin secretion. Neuroimmunomodulation. 2013;20:341-7.

\section{Publisher's Note}

Springer Nature remains neutral with regard to jurisdictional claims in published maps and institutional affiliations. 